\title{
IMPLEMENTASI STRATEGI 5R UNTUK MENGOPTIMALKAN KETERAMPILAN ABAD 21 MAHASISWA PGSD
}

\author{
Nur Asyiah, Sati \\ Universitas Muhammadiyah Cirebon, Indonesia \\ nurasyahm@gmail.com
}

\begin{abstract}
The $21^{\text {th }}$ Century is inseparable with the thing so-called 'digital technology'. Students are now definitely dependent to some internet platforms, such as yahoo or google, while trying to solve their learning queries, yet they do not thoroughly analyze the source, and it is so often that the papers of those students are merely the copies of the ones available online. In this digital era, a student ought to possess the skill to find the right information. Teachers should take their roles in order to optimize this kind of skill in their students. This research observed the application of a strategy namely $5 R$ which is said to be complementary to the learning characteristic of the students of 21th century. The purpose of this study was to observe the effectivity of $5 R$ (Research-based method, Relevance, Rational, Relaxed and Rapport) in affecting the skills of nowadays students. The effectivity was observed through student'slevel of creativity, critical thinking, communication and collaboration. This research was conducted by using 'control group posttest only' design, with the senior PGSD student of UniversitasMuhammadiyah Cirebon, who were taking the course namely 'the innovation in education', as the research subject. In order to find the effectivity level of $5 R$ (Research-based method, Relevance, Rational, Relaxed and Rapport), the researcher conducted homogeneity test and $t$ test. The mean value of the control group was 3.60 and the mean value of the experiment group was 3.86. This result indicated that there was a difference in these mean values. Through the $t$ test, the researcher found that the value of $5 R$ effectivity on the skill to find the right information (in the context of learning activity occurred in the course of 'innovation in education') was 0.032. This value is smaller than 0.05, meaning that the application of $5 R$ could be deemed influential to the enhancement of student's skill in finding the right information online.
\end{abstract}

Keyword: 21st century skills, $5 R$ strategy

\section{Abstrak}

Abad 21 berkaitan erat dengan teknologi digital, sehingga mahasiswa yang banyak tergantungan dengan internet atau yahoo dan google untuk menyelesaikan setiap permasalahan dalam pembelajaran, bahkan tidak menganalisis sumber yang dilihat dan ditemukan tugas yang sama dengan makalah yang ada di internet. Padahal keterampilan tersebut sangat penting dimiliki oleh siswa di era digital saat ini. Sehingga perlu peran dosen dalam mengoptimalkan keterampilan mahasiswa di abad 21. Dalam penelitian ini mencoba menerapkan strategi $5 \mathrm{R}$, yang sesuai dengan karakteristik dengan pembelajar di abad 21. Tujuan penelitian ini yaitu untuk melihat efektifitas penggunaan strategi $5 R$ (Research-based method, Relevance, Rational, Relaxed, and Rapport), terhadap keterampilan mahasiswa di abad 21. Hal ini dilihat dari keterampilan creativity, Critical Thinking, Communication, Colaboration. Desain penelitian yang digunakan yaitu control grouph post test only design. Penilitian ini dilakukan di semester v prodi PGSD Universitas Muhammadiyah Cirebon pada matakuliah inovasi pendidikan. untuk melihat efektifitas penggunaan strategi 5R (Research-based method, Relevance, Rational, Relaxed, and Rapport) ini, dianalisis menggunakan uji homogenitas dan uji t. Di kelas kontrol memperoleh mean sebesar 3,60 dan kelas eksperimen 3,86, hal ini menunjukan terdapat perbedaan nilai rata-rata keduanya. Hasil uji-t nilai pembelajaran inovasi pendidikan menggunakan strategi $5 \mathrm{R}$ adalah sebesar 0,032 pada keterampilan abad 21, karenakan kurang dari 0,05 maka penggunaan strategi $5 \mathrm{R}$ ini dianggap berpengaruh terhadap peningkatan keterampilan abad 21.

Kata Kunci: keterampilan abad 21, strategi 5R

\begin{tabular}{llll}
\hline Received & $: 2019-11-26$ & Approved & $: 2020-01-04$ \\
Reviesed & $: 2020-01-03$ & Published & $: 2020-01-08$
\end{tabular}

(c) (†) Jurnal Cakrawala Pendas is licensed under a Creative Commons Attribution-ShareAlike
4.0 International License. 


\section{Pendahuluan}

Situasi abad 21 sering kali diidentifikasi masyarakat informasi, yang ditandai oleh munculnya masyarakat digital. Di era ini, kemudian mucul apa yang disebut sebagai Industry 4.0. Industri 4.0 adalah tren terbaru teknologi yang sedemikian rupa canggihnya, yang berpengaruh besar terhadap proses produksi pada sektor manufaktur. Ciri utama masyarakat informasi adalah semua masyarakat berbasis pada pengetahuan. Perubahan menuju masyarakat yang berpengetahuan (knowledge society) yaitu menuntut masyarakat menguasai keterampilan abad 21. Pendidikan memliki peran penting dalam membangun masyarakat yang berpengetahuan. Menurut Rusdin (2018: 1295) keterampilan di abad 21 diantaranya 1). Melek teknologi dan media; 2. Melakukan komunikasi efektif; 3). berfikir kritis; 4). Memecahkan masalah; dan 5). Berkolaborasi.

Hadirnya ICT di era milenial ini memiliki dampak positif yaitu diantaranya perubahan sistem pembelajaran berbasis digital, selain itu juga akses informasi yang sangat terbuka lebar sangat mudah diakses mahasiswa, serta memudahkan dosen dalam menjangkau sumbersumber belajar yang terkini. Namun di era digital ini, tentunya menghadirkan persoalan baru yaitu ketergantungan mahasiswa terhadap google dan yahoo dalam menghadapi masalah ataupun penugasan dalam pembelajaran di kelas. Misalnya saja ketika diberikan permasalahan atau tugas mahasiswa mencoba mencari solusi dari internet, tanpa mendiskusikan dengan kelompok dan mencarikan solusi dari permasalahan yang ada, kadang pembuatan makalah yang dibuat sama persis dari yang ada di internet. Hal ini merupakan kesenjangan dari keterampilan atau karakter siswa di abad 21 yaitu kemampuan dalam melakukan komunikasi, berfikir kritis, memecahkan masalah dan berkolaborasi yang tidak sesuai dengan harapan di abad 21. Hal ini perlu adanya peran seorang guru dan dosen dalam mengarahkan mahasiswa mengembangkan keterampilan di abad 21 ini.

Di abad 21 seharusnya dalam pembelajaran mulai meninggalkan pembelajaran tradisional yaitu sudah menggunakan teknologi, pembelajaran berbasis penelitian dan saling bekerjasama bekerja dalam tim. Penggunaan teknologi bisa digunakan sebagai sumber atau alat pembelajaran, seperti penggunaan social media dalam pembelajaran ini memudahkan peserta didik dalam mengkomunikasikan apa yang baru saja dia pelajari dari hasil pembelajaran. Menurut Boholano (2017: 23) jejaring sosial mudah dan cepat dalam mengakses, meninjau, memperbaharui dan mengedit kebutuhan materi pembelajaran kapan saja dan dimana saja. Selain itu juga penggunaan blog yang memungkinkan pengguna mempublikasikan pembaharuan teks secara online. Tentunya hal ini bisa dimanfaatkan dalam kegiatan pembelajaran di kelas. Pada intinya guru memiliki peran utama dalam menciptakan kriteria pembelajaran sesuai abad 21 seperti dalam penggunaan strategi pembelajaran ataupun pengintegrasian teknologi dalam rutinitas kelas.

\section{Metode Penelitian}

Penelitian ini dilakukan pada mahasiswa Universitas Muhammadiyah Cirebon (UMC) semester v tahun ajaran 2019/2020. Penelitian ini dengan menerapkan strategi 5R (Researchbased method, Relevance, Rational, Relaxed, and Rapport) pada matakuliah inovasi pendidikan. penelitian ini memiliki tujuan mengetahui efektifitas penggunaan strategi $5 \mathrm{R}$ pada matakuliah inovasi pendidikan. penelitian ini menggunakan desain penelitian posttest only control grup design, dalam kelompok ini dipilih secara random (R), pada kelompok pertama diberikan 
perlakuan menggunakan strategi 5R, kelompok kedua tidak menggunakan strategi 5R. Kemudian diberikan posttest pada masing-masing kelompok, kemudian dilakukan analisis uji beda menggunakan $\mathrm{t}$ test.

\section{Hasil dan Pembahasan}

Pada abad 21, pendidikan terjadinya pergeseran arah dan tujuan. Hal ini dipengaruhi oleh kemajuan sains dan teknologi. Perubahan tujuan atau mindset manusia di abad 21 menuntut pula perubahan besar dalam tujuan pendidikan nasional. Hal ini dikarenakan agar bangsa indonesia agar mampu bersaing seiring dengan berkembangnya zaman. P21 (Partnership for 21st century Learning) mengembangkan frame work pembelajaran di abad 21 yang menuntut peserta didik untuk memiliki keterampilan, pengetahuan dan kemampuan dibidang teknologi, media dan informasi, keterampilan pembelajaran dan inovasi keterampilan hidup dan karir (P21, 2015). Menurut Trilling dan Fadel (Wijaya, 2016) keterampilan abad 21 yaitu keterampilan hidup dab Berkarir, Keterampilan Belajar dan Berinovasi, Keterampilan Teknologi dan media informasi.

Adapun penjelasan framework menurut (BNSP:2010) adalah sebagai berikut: 1). Kemampuan berfikir kritis dan pemecahan masalah (Critical-Thinking and Problem-Solving Skill); 2). Kemampuan berkomunikasi dan bekerjasama (Communication and Collaboration Skills); 3). Kemampuan mencipta dan memperbaharui (Creativity and Innovation Skill); dan 4). Literasi teknologi informasi dan Komunikasi (Information and Communication Technology Literacy). Menurut nahdi (2019:136) setiap orang yang hidup di abad 21, setidaknya memiliki 4 keterampilan berfikir kritis, berfikir kreatif, keterampilan komunikasi dan keterampilan kolaborasi.

Dalam generasi milenial akan membutuhkan beberapa keterampilan-keterampilan yang dibutuhkan di abad 21. Menurut Helen (2017: 24), "The Internet provides numerous venues for pre service teachers to share their views,preferences, lessons or experiences with others as well as opportunities to teach and learn. Social networking sites provide easy-to-use tools for all users to invite others to join the network". Tersedianya internet secara terbuka tentunya itu sangat mempermudah setiap orang untuk berbagi berbagai hal berupa pengalaman atau pelajaran. Tentunya dapat diakses secara bebas oleh setiap orang dimana pun dan kapan pun. Namun seringkali kemudahan tersebut dsalah gunakan oleh mahasiswa dalam mengerjakan setiap tugasnya. Dengan adanya akses internet yang mudah, sehingga menurunnya keterampilan abad 21yaitu sikap yang kritis dan inovatif, cenderung tidak adanya kolaborasi dengan teman sejawat.

Strategi yang akan digunakan dalam penelitian ini yaitu strategi $5 \mathrm{R}$ (Research-based method, Relevance, Rational, Relaxed, and Rapport). Menurut Price (2011) strategi yang digunakan untuk mengajar mahasiswa di era milenial yaitu, 1). Research-based method yaitu pengajaran berbasis kepada metode penelitian, peserta didik tentunya akan lebih menarik ketika mereka belajar melakukan melalui kegiatan penelitian-peneltian terkait bahan ajar yang telah dikaji; 2). Relevance, yaitu membuat bahan ajar, atau hal yang dikaji disesuaikan dengan ilmu pengetahuan yang relevan saat ini atau sesuai dengan permasalahan-permasalahan nyata yang terjadi terutama dalam dunia pendidikan; 3). Rational, yaitu mengajak mahasiswa untuk bersikap atau menentukan segala sesuatu bukan hanya dari komando dosen, namun dapat menentukan segala sesuatu bersifat rasional berdasarkan fakta, referensi, kejadian-kejadian yang dilihat; 4). Relaxed, yaitu peserta didik di ajak melakukan pembelajaran yang santai namun beretika sehingga, memudahkan mahasiswa memahami konsep yang akan dipelajari. 
5). Rapport, ciptakan pembelajaran yang nyaman, seperti membentuk hubungan yang baik antara mahasiswa dengan dosen.

Hasil dari penelitian ini yaitu untuk melihat perbedaan keterampilan abad 21 pada kelas kontrol dan eksperimen. Adapun data yang diperoleh sebagai berikut:

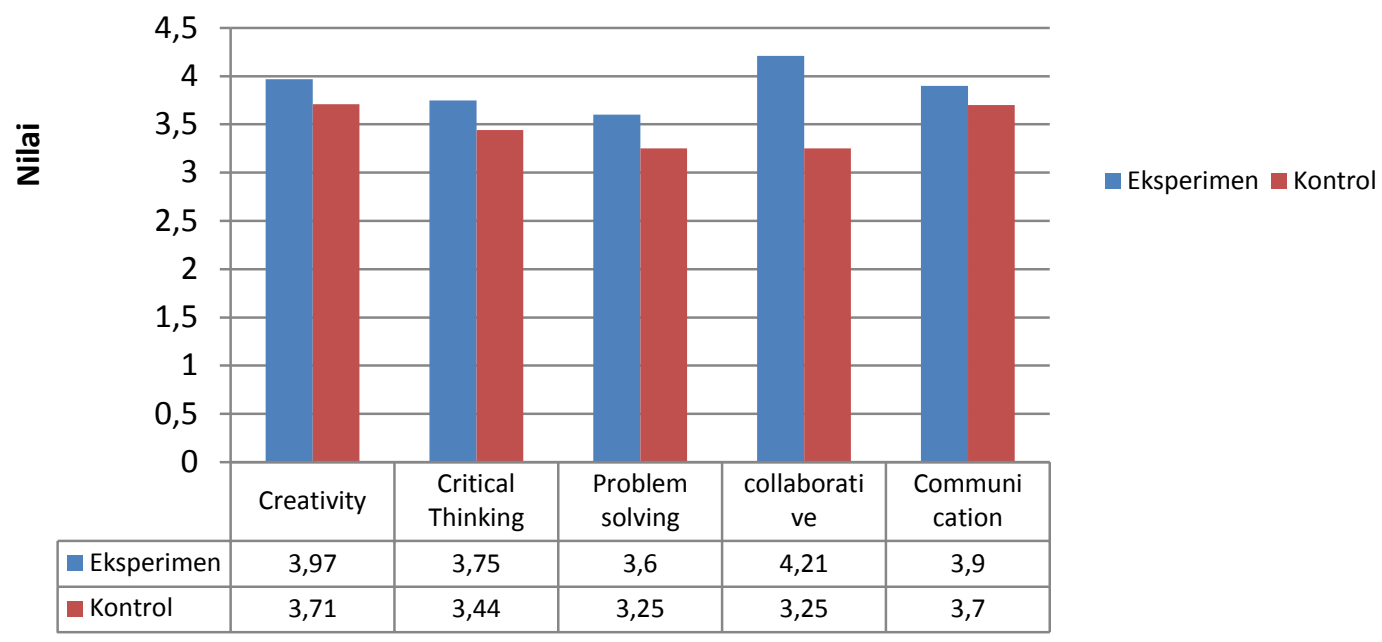

Gambar 1 Rerata Skor keterampilan abad 21 Mahasiswa PGSD

\section{Keterampilan Kreatifitas (Creativity)}

Data tersebut diperoleh rata-rata 3,71 untuk kelompok kontrol dan 3, 97 untuk kelompok eksperimen yaitu terdapat perbedaan antara kedua kelompok. Untuk kelompok yang menggunakan strategi 5R (Research-based method, Relevance, Rational, Relaxed, and Rapport), mahasiswa mampu menciptakan inovasi dalam dunia pendidikan berbasis masalah yang ada disekolah. Selain itu bahan ajar yang dibahas setiap harinya mengkaji permasalahan yang relevan dalam permasalahan pendidikan saat ini. Sehingga mahasiswa memberikan peserta didik berfikir kreatif. Berbeda dengan kelas kontrol mahasiswa cenderung sulit menciptakan ide-ide yang baru dan luas. Sehingga lebih terfokus kepada buku referensi yang ada. Selain itu juga sensitifitas terhadap suatu permasalahan sehingga produk yang dihasilkan memiliki kriteria compatibel yang rendah karena memiliki tingkat urgensi yang rendah. Karena menurut guilfords (1983) beberapa faktor yang mempengaruhi menciptakan pruduk yang berbeda yaitu sesorang memiliki sensitifitas yang tinggi terhadap suatu masalah, memiliki ide yang cemerlang, mampu mensisntesis, menganalisis dan mengevaluasi kemampuan. Internet merupakan suatu unsur dominan yang tidak bisa dipisahkan, sehingga mahasiswa tidak bisa lepas dari internet. sehingga mahasiswa perlu diberitahukan teknis-teknis dalam hal menyusun tugas atau membuat makalah, laporan, sehingga untuk meminimalisir itu dibuatkan tugas berbentuk projek penelitian.

2. Keterampilan Berfikir Kritis dan Pemecahan Masalah (Critical Thinking and Problem Solving)

Kemampuan berfikir kritis dan kemampuan memecahkan masalah terdapat perbedaan. Untuk kemampuan berfikir kritis pada pembelajaran yang menggunakan strategi $5 \mathrm{R}$ (Research-based method, Relevance, Rational, Relaxed, and Rapport) dan yang tidak 
menggunakan terjadi perbedaan yang tidak banyak. Pada indikator membuat hubungan antara informasi dengan argumen mahasiswa sudah terbiasa, namun pada indikator menganalisis dan mengevaluasi bukti, klaim dan keyakinan secara efektif memiliki perbedaan yang signifikan dikarenakan dalam pembelajaran $5 \mathrm{R}$ terbiasa belajar melalui permasalahan-permasalahn faktual.

Pada kemampuan memecahkan masalah mahasiswa PGSD ketika diterapkan strategi $5 \mathrm{R}$, mahasiswa terbiasa untuk menyelesaikan permasalahan-permasalahan yang terkait dalam dunia pendidikan. yaitu dengan mengklarifikasi sejumlah pandangan sehingga menghasilkan solusi yang terbaik dan tepat dalam menyelesaikan masalah. Menurut Lombardi (2007) siswa itu lebih termotivasi mengikuti pembelajaran dalam menyelesaikan permaalahan dunia nyata. Sehingga memperoleh beragam pengalaman baru yang menyenangkan. Hal ini juga terlihat antusias mahasiswa dalam melakukan pembelajaran.

3. Keterampilan Kolaboratif (Collaborative)

Kemampuan kolaborasi merupakan siswa mampu berkerjasama dan beradaptasi dalam kondisi yang berbeda, serta bekerja produktif dengan oranglainnya. Keterampilan ini sering dioptimalkan melalui penggunaan metode-metode pembelajaran kolaboratif seperti biasanya di dalam kelas, sehingga peserta didik mampu bekerja dengan tim. Tapi hal ini belum optimal dikarenakan masih banyak mahasiswa yang bekerja secara individu, mahasiswa yang lepas tanggung jawab terhadap tugasnya.

4. Keterampilan Komunikasi (Communication)

Keterampilan komunikasi merupakan hal yang penting dalam melakukan pekerjaan. Menghasilkan pekerjaan yang baik tentunya salah satunya dipengaruhi oleh komunikasi yang baik, baik secara tertulis maupun lisan. Dengan adanya internet memudahkan sesorang dalam melakukan komunikasi secara online serta membangun dan memelihara jaringan pertemanan. Sehingga kemampuan komunikasi mahasiswa dengan adanya media sosial cenderung lebih menyukai komunikasi tanpa tatap muka. Mahasiswa juga terlihat individual dan tidak sensitif terhadap lingkungan disekitarnya. Menurut rahman (Wood \& Hartshorne, 2017) rendahnya kemampuan komunikasi dapat berpengaruh pada kemampuan memproses informasi, kesulitan mengintegrasikan fikiran dan ucapan, dan kesulitan beradaptasi dengan lingkungan. Berdasarkan data tersebut terdapat perbedaan mahasiswa terbiasa berkomunikasi mengemukakan ide-ide atau gagasan dengan baik berdasarkan data yang ada, melalui media social dan blog yang mereka buat. Mahasiswa juga mampu memproses informasi berdasarkan pesan yang telah disampaikan oleh pemberi pesan sehingga tidak menerima informasi secara utuh.

Uji pengaruh perangkat pembelajaran strategi $5 \mathrm{R}$ diperoleh dari keterampilan abad 21 , yang dilakukan dengan memberikan angket yang berisi 48 pernyataan. Skor post test kelas eksperimen lebih tinggi daripada kelas control baik keterampilan kreativitas dan inovasi, berfikir kritis dan memecahkan masalah, kolaboratif dan komunikatif. Selanjutnya dilakukan uji pengaruh penerapan strategi 5R (Research-based method, Relevance, Rational, Relaxed, and Rapport) terhadap keterampilan abad 21 mahasiswa menggunakan uji-t. kriteria pengujian yang digunakan adalah jika sig lebih besar dari $\alpha=0,05$. Berdasarkan hasil uji homogenitas diperoleh data $p=0,32$, karena $p$ di atas 0,05 maka data homogen atau tidak ada perbedaan varians antara kemampuan keterampilan abad 21 di kelas kontrol dan eksperimen. Kemudian diperoleh $t$ tabel 3,49, karena $t$ tabel lebih dari 0,05 maka terdapat perbedaan keterampilan abad 21 dikelas eksperimen dan kelas kontrol. 


\begin{tabular}{llrrrr}
\multicolumn{7}{c}{ Group Statistics } \\
\hline & Kelas & $\mathrm{N}$ & Mean & $\begin{array}{c}\text { Std. } \\
\text { Deviation }\end{array}$ & \multicolumn{2}{c}{$\begin{array}{c}\text { Std. Error } \\
\text { Mean }\end{array}$} \\
\hline $\begin{array}{l}\text { keterampilan } \\
\text { abad 21 }\end{array}$ & eksperimen & 22 & 3.8636 & .29688 & .06330 \\
\cline { 2 - 7 } & 2.00 & 22 & 3.6000 & .19272 & .04109 \\
\hline
\end{tabular}

Selain itu diperoleh rata-rata di kelas eksperimen 3,86 dan kelas kontrol 3,60. Hal ini memiliki arti 3,86>3,60 yaitu keterampilan abad 21 dikelas eksperimen lebih tinggi dibandingkan kelas kontrol. Sehingga dapat disimpulkan terdapat perbedaan kemampuan keterampilan abad 21 pada pembelajaran inovasi pendidikan di SD dengan menggunakan strategi 5R (kelas eksperimen) secara signifikan lebih baik dari pada kelas kontrol. Mengajar di era 21 cukup menantang karena fokus kepada keterampilan kreativitas, komunikasi, kolaborasi dan berfikir kritis. Menanamkan keterampilan abad 21 pada siswa terdapat beberapa faktor yang mempengaruhi karena setiap siswa memiliki perbedaan dalam pengetahuan, semangat, motivasi dan gaya belajar. Namun menurut Rusdin (2018) pengajaran menggunakan strategi pembelajaran memainkan peran penting dalam menarik peran siswa terhadap suatu subjek dan mampu memudahkan menghubungkan antara subjek yang dipelajari. Selain itu guru perlu kreatifitas dalam merancang pembelajaran sehingga menghasilkan pembelajaran bermakna.

\section{Kesimpulan}

Penerapan strategi 5R (Research-based method, Relevance, Rational, Relaxed, and Rapport) pada matakuliah inovasi pendidikan yaitu membuat mahasiswa menjadi (1) mampu menciptakan produk inovatif, (2) mampu bekerja dengan tim, dan (3) mulai terbiasa belajar berbasis penelitian. Selain itu diperoleh rata-rata di kelas eksperimen 3,86 dan kelas kontrol 3,60. Hal ini memiliki arti 3,86>3,60 yaitu keterampilan abad 21 dikelas eksperimen lebih tinggi dibandingkan kelas kontrol. Sehingga dapat disimpulkan terdapat perbedaan kemampuan keterampilan abad 21 pada pembelajaran inovasi pendidikan di SD dengan menggunakan strategi 5R (kelas eksperimen) secara signifikan lebih baik dari pada kelas kontrol.

\section{Daftar Pustaka}

Benfer. E. Dan Shanahan. C. F. (2013). Educating the Invincibles: Strategies for Teaching the Millennial Generation in Low School. 20 CLINICALL. REV. 1

Boholano, H. B. (2017). Smart Social Networking: 21st Century Teaching and Learning Skills. Cebu Normal University. Research in Pedagogy. Vol 7, Issue 1 Hal 21-29

Center for Curriculum Redesign. (2015). Character Education for 21 th Century.

Erawati, M. 2016. Pembentukan Rapport di Kelas:Analisis Psikologi. Psikohumaniora: Jurnal penelitian sosiologi. vol. 1 No. 1 Halaman 75-94

Grover. T. P. Dan Groscurt. C. R. (2009). Priciples Teaching The Millennial

Guilfod, J. P. (1983). Creatividad Y Educacion. Spain: Paidos 
Hidayah, R. (2018). Implementasi Research Based Learning pada mata kuliah Media Pembelajaran: Penelitian Kelas pada Calon Guru. Jurnal Bidang Pendidikan Dasar (JBPD)Vol. 2 No. 2

Nahdi, D.S. (2018). Keterampilan Matematika Abad 21. Jurnal Cakrawala Pendas vol. 5 No. 2

Piirto, J. (2011). Creativity for 21st Century Skills: How to Embed Creativity into the Curriculum.. Ashland University: Sense Publisher

Price, C. (2011). Five Strategies to Engage Today's Students. Magna Online Seminar.

Rusdin, N. M. (2018). Teachers Readiness in implementing 21st Century Learning. International Juornal of Academic Research in Business \& Social Sciences. Vol. 8 No. 4. Hal 1293-1306

Wijaya, E. Y, Sudjimat, D. A, dan Nyoto. A. (2016). Transformasi Pendidikan Abad 21 Sebagai Tuntutan Pengembangan Sumber Daya Manusia di Era Global. Prosiding Seminar Nasional Pendidikan Matematika. Universitas Kanjuruhan Malang Volume 1 ISSN 2528$259 \mathrm{X}$

Willis, J. (2006). Research-based strategies to ignite student learning:insigt from a neurologist and clasroom teacher. ASCD 